\title{
Google Classroom: Understanding EFL Students' Attitudes towards Its Use as an Online Learning Platform
}

\author{
Jitlada Moonma $^{1}$ \\ ${ }^{1}$ The Faculty of Humanities and Social Sciences, Lampang Rajabhat University, Lampang, Thailand \\ Correspondence: Jitlada Moonma, The Faculty of Humanities and Social Sciences, Lampang Rajabhat University, \\ Lampang, Thailand.
}

Received: September 19, 2021

Accepted: October 11, 2021

Online Published: October 13, 2021

doi: $10.5539 /$ elt.v14n11p38

URL: https://doi.org/10.5539/elt.v14n11p38

\begin{abstract}
The closure of educational institutions across Thailand, as well as the maintenance of social distancing as a preventive and precautionary step against COVID-19, has thrown a wrench in the traditional method of teaching, which has given way to online learning. As a result, most online learning is managed through a learning management system, the most popular of which is Google Classroom. The purpose of this study was to find out how students felt about using levels as a virtual learning tool. One hundred and eleven second-year Thai EFL students from 7 majors who are taking English for Work participated in this study. They were mostly female (79.28\%) and between 19 and 23 years old. They had attended online learning on Google Classroom. To obtain participants' feedback, a Google Form questionnaire and a semi-structured interview were used. Means and Standard deviation were used as descriptive statistics. According to the results of the study, students indicated positive attitudes towards using Google Classroom in the aspect of ease of use (Mean $=4.41$ ), usefulness (Mean $=4.12$ ), and intention to use (Mean $=4.02)$. The results showed Google Classroom was well perceived by students. They perceived Google Classroom to be useful in submitting assignments and reminding class announcements. The results help teachers to consider arranging activities such as live online tutoring and discussion using Google Classroom to enhance students' learning engagement or using blended learning (integrating online learning mode with face-to-face classroom).
\end{abstract}

Keywords: Google Classroom, intention to use, online learning platform, perceived ease of use, perceived usefulness, Technology Acceptance Model

\section{Introduction}

In the 21 st century, education has continued to evolve, it is now being shaped by modern advances in information and communication technology, or ICT (Thongphan, 2020). Since 2019, the pandemic has disrupted education and forced teachers to rely on technology in new ways. Teachers have faced an unstable year and are forced to consider how technology could be used to keep learners safe and engaged in education during the COVID-19 pandemic. Moreover, they are having students of all ages studying, submitting assignments, and interacting with teachers and classmates online.

Several online platforms can be made part of the curriculum, used as a means to deliver instructions, incorporated to help instructions, and used to make the overall learning process and improved experience (Raja \& Nagasubramani, 2018). Classrooms with technology are not only more effective but also enjoyable (Al-Mekhlafi, 2020). Furthermore, according to the study of AlMekhlafi (2020), classrooms with technology make students more motivated to learn about the subjects. In language classrooms, classrooms that use technology have been shown to produce positive results (AlMekhlafi, 2006; Awad \& Alkaraki, 2013; Kitchakarn, 2015). Technology enhanced classrooms not only benefits students but also teachers (Wu, Hsieh, \& Yang, 2017).

With the advancement of technology, there have emerged new learning and teaching innovations. Instead of occurring in physical interactions, learning can now take place online (Dhawan, 2020). As defined by Singh and Thurman (2019), online learning refers to "learning experiences in synchronous and asynchronous environments using different devices (e.g. mobile phones, laptops, etc.) with internet access." (p. 289). Nowadays, the use of online learning at the university level has increased (Ansong-Gyimah, 2020). Online learning is commonly managed through a Learning Management System (LMS), a web-based system that allows teachers and students 
to always be connected (Abedalaziz, Jamaluddin, \& Leng, 2013). LMS helps teachers to organize online courses (Aldiab, Chowdhury, Kootsookos, Alam, \& Allhibi, 2019). Through LMS, teachers can engage in several activities, such as communicating with students, share classroom materials, give quizzes and assignments, and mark and return assignments, while students can access materials, submit assignments, and interact with each other (Lonn \& Teasley, 2009). One of the most popular LMSs is Google Classroom. Across the globe, Google Classroom is used by thousands of schools and universities aiming to take advantage of its features to enhance their learning and teaching (Afeez, 2020).

Technology, such as online learning, is only as beneficial and effective as the learners' willingness to accept and use it. Some students may not see online learning as beneficial and refuse to use it, resulting in a waste of time and resources. As such, learners' degree of acceptance of online learning needs to be determined. One of the pertinent models commonly used for this purpose is the Technology Acceptance Model (Davis, 1989). Most studies by researchers in the field have shown that users of Google Classroom view its ease of use, usefulness, and helpfulness positively (Al-Mekhlafi, 2020; Albashtawi \& Al Bataineh, 2020; Sepyanda, 2018). However, studies on Google Classroom involving Thai EFL learners are few (Thongphan, 2020). Even scant are studies that involved Thai EFL students taking English subjects. Therefore, closing this gap in the literature was the aim of the present study.

The purpose of this study was to find out how Thai EFL university students felt about using Google Classroom as an online learning platform. Quantitative descriptive research was used, with data obtained via a survey, and qualitative research was used, with data acquired via semi-structured interviews. The following were the research questions:

1) Do students perceive Google Classroom as easy to use?

2) Do students perceive Google Classroom as useful?

3) Do students intend to use Google Classroom over other methods and platforms?

\section{Literature Review}

\subsection{Google Classroom}

Google Classroom was developed by Google Inc. for academic institutions and was publicly launched on August 12, 2014. Google Classroom is a free platform in the Google Apps, non-profits, and easy for students and teachers to connect inside and outside class. Furthermore, it is designed to make teachers' lives a little easier and more organized. This application saves time and is paperless, and makes it easy to manage classes, give assignments, communicate and be systematic (Hulse, 2019).

According to Hulse (2019), Google Classroom is designed to help teachers organize, collect and mark assignments paperless, including time-saving features which automatically make a copy of a Google document for each student. Classrooms also help teachers and students stay organized. It automatically creates a Drive folder for each assignment and students can track their assignments page. Teachers can quickly track the assignments' progress and provide direct, real-time comments and scores in it. Students can see their assignments and work on them right from their devices. Furthermore, students and teachers receive notifications and reminders when they have new content in Classroom, so they are always up to date.

First and foremost, Google Classroom is simple to handle; teachers can invite students directly or provide a code for them to join the newly created classroom. Managing a class takes only a few minutes. Secondly, paperless assignment saves time by allowing teachers to create, evaluate, and grade assignments all in one application. Thirdly, students can view their assignments and class resources (such as documents, images, and videos), which are saved in Google Drive folders automatically. Fourthly, it saves teachers time by allowing them to produce and collect student assignments without wasting paper. Teachers may also check who has completed and who has not completed their work, as well as provide individual feedback to pupils. It also allows them to make real-time announcements, ask questions, and interact with kids. Students can use the stream to share materials with their peers or to respond to questions. Finally, for educational institutions' security, the program has no adverts, and neither instructor content nor student data will be used for commercial purposes.

Regarding the attitudes on Google Classroom, Heggart and Yoo (2018), Putra (2020), and Wan (2020) found that students strongly agreed to the use of Google Classroom in teaching and learning because they can access the information from the very same source through a variety of devices such as laptops, mobile phones or tablets any time. Al-Maroof and Al-Emran (2018) found that when Google Classroom was integrated into their learning, students felt motivated. Khalil (2018) found that students viewed Google Classroom as supporting a collaborative learning environment since it allows teacher-student and student-student interactions. Another 
study by Beguin, Besnard, Cros, Joannes, Leclerc, Noel, and Nicomette (2019) also explored the students' satisfaction with Google Classroom. The findings revealed that the learner's satisfaction with the system overall was the "most". However, few studies examined the attitudes of Thai EFL students towards Google Classroom. Some studies are arguing that students' attitudes towards Google Classroom may differ depending on their environments. Therefore, while most studies have reported students' positive attitudes, a few studies found contrasting results.

\subsection{Students' Attitudes towards Google Classroom as a Learning Management System (LMS)}

Several studies were conducted about the students' attitude towards and acceptance of the Learning Management System (LMS) by using the Technology Acceptance Model (TAM) of Davis (1989). The research study of Al-Maroof and Al-Emran (2018) conducted at Al Buraimi University College (BUC) in Oman proved that both the perception of ease of use and usefulness in TAM positively affects the behavioral intention, which in turn affects Google classroom usage. This was supported by the research study of Trayek and Sariah Syed Hassan (2013) conducted to both full-time and online learning students at the International Islamic University in Malaysia (IIUM) which proved that perceived ease of use and usefulness towards the use of LMS. A parallel study conducted by Kumar and Bervell (2019) investigated students' attitudes on Google Classroom as a mobile learning platform. The findings revealed significant non-linear relationships between motivation and habit. Students' intentions were positive to accept that Google Classrooms were related to habit, motivation, and performance expectancy. The research study of Munasinghe and Percy (2016) conducted among the students of Rajarata University of Sri Lanka also supported the previous research. The study indicated that perceived usefulness and ease of use have significant effects on the attitude towards the use of LMS. It confirmed that students have positive attitudes toward Google Classroom. It was similar to the research study of Indahyanti \& Sukarjadi (2015), revealing that the factors influencing students' acceptance of an LMS at Politeknik SAKTI Surabaya are perceived usefulness, perceived ease of use, and attitudes towards use, affecting the intention to use and significantly affecting the actual use of LMS. Furthermore, in the study of Alshorman \& Bawaneh (2018) the students' attitudes towards using learning management systems in Teaching and learning were positive.

\subsection{The Framework of Technology Acceptance Model}

Several studies explain the concept of technology adoption. One of the most accepted models is the Technology Acceptance Model (Davis, 1989). Technology Acceptance Model (TAM) presents important factors (ease of use and usefulness) that determine users' attitudes towards adopting technology (Malhotra \& Galletta, 1999). Technology Acceptance Model has been used in a number of studies on mobile services (Amberg, Hirschmeier, \& Wehrmann, 2004; Pagani, 2004; Phan \& Daim, 2011; Teo \& Pok, 2003). Even though TAM is supposedly used to explain the adoption of technology within an organization, the model is meant to be universal. TAM, as illustrated in Figure 1, includes 5 concepts (Malhotra \& Galletta, 1999; Davis, 1989):

- External variables are defined as variables that affect perceived usefulness, perceived ease of use, and attitude towards using.

- Perceived usefulness means that a person believes that using the particular system/technology will improve his or her action (Venkatesh \& Davis, 2000).

- Perceived ease of use shows that a person believes that using the particular system/technology is simple (Venkatesh et al., 2003).

- Attitudes towards usage indicate the users' desirability to use the particular system/technology (Malhotra \& Galletta, 1999).

- Behavioral Intention (BI) is predicted by attitude towards usage combined with perceived usefulness. 


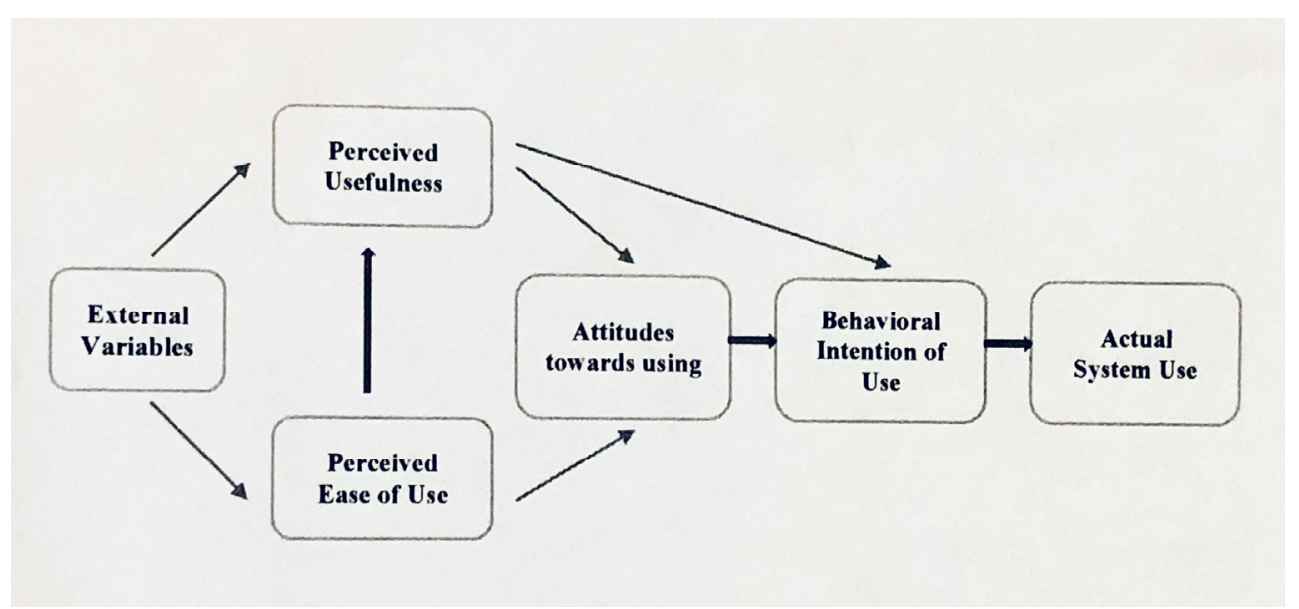

Figure 1. The Framework of "Technology Acceptance Model” (Davis, 1989)

\section{Method}

\subsection{Participants}

Purposive sampling was utilized to choose 111 second-year students from a Thai northern college who participated in the English for Work Course. Their ages varied from 19 to 23. Based on their previous grades of English Communication and Study Skills course in the previous academic year, the levels were assessed to be at low, intermediate, and advanced as follows:

$$
\begin{array}{ll}
\text { Advanced: } & \mathrm{A}(80-100) \\
& \mathrm{B}+(75-79) \\
\text { Intermediate: } & \mathrm{B}(70-74) \\
& \mathrm{C}+(65-69) \\
\text { Low: } & \mathrm{C}(60-64) \\
& \mathrm{D}+(51-59) \\
& \mathrm{D}(49-50)
\end{array}
$$

The English for Work course they were taking consisted of 16 weeks of face-to-face sessions in the classroom, including a midterm and final test. The Thai government has imposed the Movement Control Order since the country was afflicted by the COVID-19 outbreak. The university was expected to administer all online learning settings under the regulations. The participants took Google Classroom classes online.

\subsection{Instruments}

\subsubsection{Questionnaire}

The survey was meant to gauge the students' feelings towards Google Classroom. Davis's (1989) and Weng, Yang, and Su's (1989) frameworks were used to create the questionnaire. There were 16 questions in total, divided into four categories. In Section 1, participants were requested to submit some demographic information. In section 2, participants were asked to rate how easy Google Classroom was to use. In Section 3, they were asked to rate how valuable Google Classroom was to them. In the final section, they were asked to rate their willingness to use Google Classroom. The replies used in Sections 2 to 4 were based on a five-point Likert scale, ranging from 1 to 5 .

$$
\begin{array}{lll}
5.00-4.20 & = & \text { Strongly agree } \\
4.19-3.40 & = & \text { Agree } \\
3.39-2.60 & = & \text { Neutral } \\
2.59-1.80 & = & \text { Disagree } \\
1.79-1 & = & \text { Strongly disagree }
\end{array}
$$

The questionnaire was constructed using Google Form and was assessed online. It allowed participants to provide their responses by clicking the chosen option for each item. The questionnaire was submitted by participants by clicking the Submit button of the Google Form. Their answers were automatically recorded. 
The researcher developed and translated the questionnaire into Thai, which was then validated by three professionals with more than 10 years of experience teaching English writing at the university level. One of them was a native speaker of the language. The three experts also offered suggestions for improving the questionnaire. Using mean and standard deviation, the validity of the questionnaire was assessed using the Index of Item Objective Congruence (IOC). The analysis yielded a result of 0.82 .

\subsubsection{Semi-Structured Interview}

Semi-structured interviews were used to acquire qualitative data from the pupils. Content analysis was used to examine the data. The interviews were conducted with forty-five students who were picked at random. Each interview was recorded in Thai using Google Meet and then translated into English. The translations were assessed in terms of semantic, idiomatic, and conceptual equivalence of the translated versions. Any discrepancies were identified, and all experts concurred. One question went something like this: What is your Google Classroom attitudes while online learning in the aspect of ease of use, usefulness, and intention to use?

\subsection{Data Collection}

After students had completed all of their assignments, the researcher invited them to participate in a survey. The study's and survey's goals were outlined by the researcher. The researcher stated that participation was not required, but rather voluntary and that by clicking the link, they were indicating their agreement. If students chose to participate, they had one week to do so, according to the researcher. For analysis, the researcher downloaded the survey responses in Microsoft Excel format.

\subsection{Data Analysis}

According to the study's objectives, the data analysis technique was divided into two parts.

Stage 1: To determine the levels of students' attitudes, Mean and Standard Deviation (SD) were used. Responses from the questionnaire were analyzed using Microsoft Excel. Data were analyzed to yield descriptive statistics.

Stage 2: To explore the students' deeper attitudes towards Google Classroom experiences, an open-ended question was asked: What are your attitudes on Google Classroom during online learning in the aspect of ease of use, usefulness, and intention to use?

\section{Results}

The study's findings and comments are given by the research topic that was proposed before.

\subsection{Demographic Information}

Table 1. Demographic Information

\begin{tabular}{llll}
\hline Item & Values & Frequency & Percentage \\
\hline Gender & Male & 23 & 20.72 \\
Age & Female & 88 & 79.28 \\
& $19-21$ & 102 & 91.90 \\
Knowledge of Internet & $22-23$ & 9 & 8.10 \\
Technology & Very Good & 12 & 10.81 \\
& Good & 67 & 60.36 \\
& Neutral & 28 & 25.23 \\
Majors & Low & 4 & 3.60 \\
& Accounting & 10 & 9.01 \\
& Communication Art & 12 & 10.81 \\
& English & 18 & 16.22 \\
& Logistics & 12 & 10.81 \\
& Marketing & 6 & 5.41 \\
& Political Science & 37 & 33.33 \\
& Tourism & 16 & 14.41 \\
\hline
\end{tabular}


A total of 111 Thai EFL second-year undergraduate students took part in this study. The demographic information of the participants is shown in Table 1. The students were in the academic year 2021 at the time of data collection. They were Thai L1 English as a Foreign Language students. During that academic year, they enrolled in the English for Work course as part of their degree program. Females made up 79.28 percent of the participants, while males made up 20.72 percent. Their ages varied from 19 to 23 years old (age 19-21 = 91.90 percent, followed by $22-23=8.10$ percent). They had very excellent knowledge of internet technology at 10.81 percent, followed by good knowledge at 60.36 percent, neutral knowledge at 25.33 percent, and low knowledge at 3.60 percent. Political Science is the major of choice for 33.33 percent of students, followed by 16.22 percent for English, 14.41 percent for Tourism, 10.81 percent for Communication Art and Logistics, 9.01 percent for Accounting, and 5.41 percent for Marketing.

Table 2. Students with Different Levels of English Proficiency

\begin{tabular}{lllll}
\hline Level of English Proficiency & Low & Intermediate & Advanced & Total \\
\hline Number of Students & 34 & 51 & 26 & 111 \\
Percentage & 30.63 & 45.95 & 23.42 & 100
\end{tabular}

Table 2 displays that the intermediate group, which had 51 students, had the highest proportion, followed by the low group, which had 34 students, and the advanced group, which had 26 students. They had used Google Classroom for a year at university before enrolling in the English for Work Course.

\subsection{Overall Students' Attitudes towards Google Classroom}

The sixteen items were grouped under three main components: perceived ease of use, perceived usefulness, and intention to use. The findings gained from the analysis are shown in Table 3.

Table 3. Mean and Standard Deviation of students' attitudes

\begin{tabular}{llll}
\hline Item & Mean & S.D. & Meaning \\
\hline Perceived ease of use & 4.41 & 0.49 & Strongly Agree \\
Perceive usefulness & 4.12 & 0.32 & Agree \\
Intention to use & 4.02 & 0.76 & Agree \\
$\quad$ Total & 4.18 & 0.52 & Agree
\end{tabular}

It can be concluded that "perceived ease of use" had the highest mean score (Mean = 4.41) and "intention to use" had the lowest mean score (Mean = 4.02). Overall attitudes on Google Classroom were at 4.18 and the interpretation was translated to Agree.

\subsection{Students' Attitudes towards Google Classroom's Ease of Use}

To determine students' attitudes towards using Google Classroom in terms of ease of use (research question 1), their responses to six items were analyzed. The item statements and students' responses are as shown in Table 4.

Table 4. Mean and Standard Deviation of Students' Attitudes towards Google Classroom' Ease of Use

\begin{tabular}{llll}
\hline Perceived Ease of Use & Mean & S.D. & Meaning \\
\hline 1. It is easy for me to sign on to Google Classroom. & 4.72 & 0.47 & Strongly agree \\
2. It is easy for me to access course materials in Google classroom & 4.32 & 0.67 & Agree \\
3. It is easy for me to receive the assignments in Google Classroom & 4.57 & 0.50 & Agree \\
$\begin{array}{l}\text { 4. It is easy for me to submit the assignments in Google Classroom } \\
\text { 5. It is easy for me to learn how Google Classroom works as a learning }\end{array}$ & 4.71 & 0.45 & Strongly agree \\
system. & 4.06 & 0.49 & Agree \\
6. It is easy for me to navigate around in Google Classroom. & 4.41 & 0.51 & Agree \\
$\quad$ Total & & & \\
\hline
\end{tabular}

Based on Table 4, the average mean of students' attitudes under the component "perceived ease of use" was 4.41. The item with the highest rating was "It is easy for me to sign on Google Classroom." (Mean = 4.72), while the lowest was "It is easy for me to learn how Google Classroom works as a learning system" (Mean $=4.05)$. 


\subsection{Students' Attitudes towards Google Classroom's Usefulness}

To determine students' attitudes towards using Google Classroom in terms of usefulness (research question 2), their responses to six items were analyzed. The item statements and students' responses are as shown in Table 5.

Table 5. Mean and Standard Deviation of Students' Attitudes towards Google Classroom' Usefulness

\begin{tabular}{llll}
\hline Perceived Usefulness & Mean & S.D. & Meaning \\
\hline 1. Google Classroom allows me to submit my assignments quickly and on time. & 4.55 & 0.68 & Strongly agree \\
2. I feel comfortable interacting with my teacher in Google Classroom. & 3.83 & 0.55 & Agree \\
3. Learning through Google Classroom is fun and interesting. & 3.91 & 0.61 & Agree \\
4. Google Classroom has made me more productive. & 3.98 & 0.44 & Agree \\
5. Google Classroom allows me to interact with the teacher and with my friends & 3.93 & 0.55 & Agree \\
effectively. & & & \\
6. I can track my progress on assignments. & 4.50 & 0.50 & Strongly agree \\
$\quad$ Total & 4.12 & 0.57 & Agree \\
\hline
\end{tabular}

According to Table 5, the average mean of students' attitudes was 4.12 . The item with the highest rating was "Google classroom allows me to submit my assignments quickly and on time" (Mean $=4.55$ ), while the item with the lowest rating was "I feel comfortable interacting with my teacher in Google Classroom." (Mean = 3.83).

The average mean of 4.12 for items under the component "perceived usefulness" translated into a high degree of agreement (Agree). It can be suggested that students agree that Google Classroom is a useful application for an online learning platform during the COVID-19 pandemic.

\subsection{Students' Intention to Google Classroom's Usage}

To determine students' attitudes level to use Google Classroom (research question 3), their responses to four items were analyzed. The item statements and students' attitudes are shown in Table 6.

Table 6. Mean and Standard Deviation of Students' Intention to Use Google Classroom

\begin{tabular}{llll}
\hline Intention to use Google Classroom & Mean & S.D. & Meaning \\
\hline 1. I will recommend using Google Classroom continuously. & 4.20 & 0.71 & Strongly agree \\
2. Google Classroom is suitable for language courses. & 4.05 & 0.21 & Strongly agree \\
3. I prefer Google Classroom instead of other online learning platforms. & 4.26 & 0.58 & Strongly agree \\
4. I prefer learning through Google Classroom instead of a face-to-face setting. & 3.59 & 0.80 & Agree \\
$\quad$ Total & 4.02 & 0.58 & Agree \\
\hline
\end{tabular}

According to Table 6, the average mean of students' attitudes under the component "intention to use" was 4.02. An item with the highest rating was "I prefer Google Classroom instead of other online learning platforms." (Mean = 4.26), while the item with the lowest rating was "I prefer learning through Google classroom instead of face-to-face setting" (Mean $=3.59$ ).

The average mean of 4.02 for items under the component "intention to use" still indicated a high degree of agreement (Agree). However, the average mean for this component was lower than those of the other factors ("perceived ease of use", "perceived usefulness").

\subsection{Students' Attitudes towards Google Classroom}

This section reported the students' deeper attitudes towards Google Classroom as an online learning application during the COVID-19 pandemic. The semi-structured interviews were started in the second phase to elicit more details of how students perceived Google Classroom. To understand the students' attitudes towards Google Classroom in all proficiency levels, a total of forty-five students were randomly selected to engage in this interview session, fifteen from each of three levels of English proficiency, were randomly selected to participate in the interview sessions administered individually. To collect this qualitative data, the following question was asked: What are your attitudes on Google Classroom during online learning in the aspect of ease of use, usefulness, and intention to use? 
In the interview process, the student' answers were translated into English using the questions in Thai. The following comments present the main category of the students' attitudes from the semi-structured interview sessions:

Regarding the easy features of Google Classroom, all students considered that Google Classroom is easy to use and accessible from all devices. Firstly, it is easy to sign in, as well as receive and submit assignments. Secondly, it is easy to post YouTube videos, links, or files from Google Drive. Thirdly, students reported that they do not have to be worried about printing, handing out, or even losing their tasks. Furthermore, the students perceived Google Classroom as a very effective communication tool because it is stored on Cloud-based, there is no more "losing" of papers.

Based on Google Classroom's effectiveness and usefulness, the students claim that they can share assignments and work from home. Collaboration isn't just limited to working with peers via face-to-face environments. It also can share screens to make collaboration easy. Furthermore, a teacher can record video, assigning students to view and prepare for a test on it the next day. Overall, students think Google Classroom is a great software that has helped them in this time of the Covid-19 pandemic. It has a great interface and is very easy to use.

According to the intention to use it, they claim that they felt motivated to continue using it. They will recommend Google Classroom to be used in all their courses in the future even though the Covid-19 pandemic disappeared in case of assigning tasks, submitting assignments to reduce paper and online collaboration out of the classroom.

However, there is a claim about online learning. The students think it's due to the lack of real face-to-face interaction in the classroom: "When I stay at home, I'm not usually in front of the computer to study... and it is quite difficult to stay motivated on one task without getting distracted."

\section{Discussion}

Based on the quantitative data, the average mean of students' attitudes under the component "perceived ease of use" was 4.41. An item with the highest rating was "It is easy for me to sign into Google Classroom." (Mean= 4.72), while the lowest was "It is easy for me to learn how Google Classroom works as a learning system" (Mean = 4.05). In comparison with the results from a recent study by Putra (2020) (Mean = 3.52) and Kassim (2021) (Mean $=4.23$ ), participants in the present study rated Google Classroom concerning its ease of use.

The average mean of students' attitudes under the component "perceived usefulness" was 4.12. An item with the highest rating was "Google classroom allows me to submit my assignments quickly and on time" (Mean $=4.55)$, while the item with the lowest rating was "I feel comfortable interacting with my teacher in Google Classroom." $($ Mean $=3.83)$. The average mean of 4.12 for items under the component "perceived usefulness" translated into a high degree of agreement (Agree). The average mean of this component was lower than that of the component "perceived ease of use". Although the students did not consider Google Classroom as high as its ease of use. Its usefulness can still be considered as a useful online learning platform. In contrast to the study of Putra (2020) and Wan (2020), participants in this study rated Google Classroom concerning its usefulness much higher. The average mean of Putra (2020) in its usefulness was only 3.22 and of Kassim (2021) was 3.92.

The average mean of students' attitudes under the component "intention to use" was 4.02. "Preferring Google Classroom as an online learning platform" was the highest level. The lowest item under the usage of Google Classroom was "preference of using Google Classroom instead of the face-to-face environment". The findings still indicated a high level of agreement (Agree). However, the average mean for this component was lower than those of the other factors ("perceived ease of use", "perceived usefulness"). It can be suggested that, although participants did not rate their intention to use Google Classroom as high as the other two factors, they were nevertheless satisfied with the features available in the platform and felt motivated to continue using it. In comparison with the results from a recent study by Putra (2020) and Kassim (2021), participants in the present study rated their intention to use Google Classroom much higher. One of the similar items in both the present study and in Putra's study was on recommending the use of Google Classroom for other courses. The mean in the present study was 4.02, while in that of Putra 3.21 and Wan 3.86. Another different item was on Google Classroom being preferred to other methods. In the present study, the mean was 4.26. In contrast, in Putra's study, the mean was only 3.10 and in Wan's results was 3.45 .

To sum up, it seems to be concluded that technology-enhanced classrooms not only benefit students but also teachers (Wu, Hsieh, \& Yang, 2017). Nevertheless, the reasons that the findings of the present study were higher than the other study might be from some factors. The percentage of the students' knowledge of technology was quite high $(\mathrm{Good}=60 \%)$. The students did not have any problems using Google Classroom. It was quite easy for 
them. Therefore, their views of Google Classroom were positive. Their attitudes in using technology have been shown to produce positive results which were similar to the findings of the study of AlMekhlafi (2006); Awad and Alkaraki (2013); and Kitchakarn (2015). Furthermore, in this study, the students have already experienced using Google Classroom for one year since the COVID-19 pandemic at the end of 2019, while the participants in Putra (2020) had attended face-to-face sessions for five weeks before using Google Classroom. Consequently, the students' experiences in using Google Classroom were different.

The findings of the present study prove that both the perceived ease of use and perceived usefulness positively influence the behavioral intention, which in turn influences the actual usage of Google Classroom. This study helps the teachers' decision to have a better understanding of the effectiveness of using Google Classroom by their students. In terms of teaching implications, the results help teachers consider the students' attitudes towards Google Classroom to implement it with the teaching methodology for example using blended learning (integrating online learning mode with face-to-face classroom) in case the COVID-19 pandemic disappeared. Furthermore, teachers could apply technology to arrange activities such as live online tutoring and discussion using Google Classroom to enhance students' learning engagement.

\section{Conclusion}

The present study aimed to determine the attitudes of 111 second-year Thai EFL in 7 majors: Accounting, Communication Arts, English, Logistics, Marketing, Political Science, and Tourism who are taking English for Work towards the use of Google Classroom as their online learning platform. Based on the results gained from the questionnaire, it was found that all students had high levels of the application. They considered Google Classroom as very easy to use, with this factor having the highest mean. They also believed that Google Classroom is highly useful in that it helped them be more productive, allowed them to access materials conveniently and submit assignments quickly, and enabled them to interact with the teacher and other friends. Overall, students thought Google Classroom was simple to use, accessible, and an effective tool, according to the qualitative data. They also expressed a strong desire to use Google Classroom. The positive sentiments of the students toward its use as an online learning platform prompted them to keep it going. Their sentiments were positive when it came to preferring it to face-to-face settings and even recommending that it be used in additional courses. The students considered Google Classroom to be simple to use, useful, and worthwhile.

\section{Limitations and Suggestions for Future Studies}

Some flaws in this study may be addressed in future research. The first limitation was the selection of participants from a public university in northern Thailand that study English as a foreign language. For greater reliability and validity, it may be suggested that the number of participants in future studies is increased threefold. Other similar studies used a huge number of people. The second constraint was the absence of correlative analysis to see if factors like age, gender, and others were significant in determining sentiments regarding Google Classroom. It may be suggested that these elements be examined further in future studies to gain a better understanding of the attitudes. The absence of analysis that established the association between students' perceptions towards Google Classroom and their academic achievement when utilizing the platform was the final restriction. It may be suggested that this analysis be carried out in future studies to see if students' positive attitudes are related to their good performance and vice versa.

\section{References}

Abedalaziz, N., Jamaluddin, S., \& Leng, C. H. (2013). Measuring attitudes toward computer and internet usage among postgraduate students in Malaysia. Turkish Online Journal of Educational Technology-TOJET, 12(2), 200-216.

Afeez, A. H. (2020). Students' attitudes and perceived usefulness of Google Classroom for learning in Oyo state colleges, Nigeria. Capital-Journal of Educational Studies (CAJES), 6(2), 46-55.

Albashtawi, A., \& Al Bataineh, K. (2020). The effectiveness of google classroom among EFL students in Jordan: An innovative teaching and learning online platform. International Journal of Emerging Technologies in Learning (iJET), 15(11), 78-88. https://doi.org/10.3991/ijet.v15i11.12865

Aldiab, A., Chowdhury, H., Kootsookos, A., Alam, F., \& Allhibi, H. (2019). Utilization of Learning Management Systems (LMSs) in higher education system: A case review for Saudi Arabia. Energy Procedia, 160, 731-737. https://doi.org/10.1016/j.egypro.2019.02.186

Al-Maroof, R. A. S., \& Al-Emran, M. (2018). Students Acceptance of Google Classroom: An Exploratory Study using PLS-SEM Approach. International Journal of Emerging Technologies in Learning, 13(6). https://doi.org/10.3991/ijet.v13i06.8275 
Almekhlafi, A. G. (2006). The effect of computer assisted language learning (CALL) on United Arab Emirates English as a foreign language (EFL) school students' achievement and attitude. Journal of Interactive Learning Research, 17(2), 121-142.

Almekhlafi, A. G. (2020). Designing and Creating Digital Interactive Content Framework: Description and Evaluation of the Almekhlafi Digital Interactive Content Model. Science Education International, 31(2), 130-141. https://doi.org/10.33828/sei.v31.i2.1

Alshorman, B. A., \& Bawaneh, A. K. (2018). Attitudes of Faculty Members and Students towards the Use of the Learning Management System in Teaching and Learning. Turkish Online Journal of Educational Technology-TOJET, 17(3), 1-15.

Amberg, M., Hirschmeier, M., \& Wehrmann, J. (2004). The compass acceptance model for the analysis and evaluation of mobile services. International Journal of Mobile Communications, 2(3), 248-259. https://doi.org/10.1504/IJMC.2004.005163

Ansong-Gyimah, K. (2020). Students' Perceptions and Continuous Intention to Use E-Learning Systems: The Case of Google Classroom. International Journal of Emerging Technologies in Learning (iJET), 15(11), 236-244. https://doi.org/10.3991/ijet.v15i11.12683

Awad, A. K. A., \& Alkaraki, S. M. S. (2013). Attitudes of EFL students towards using computers in learning English. English for Specific Purposes, 13(37), 1-20.

Beguin, E., Besnard, S., Cros, A., Joannes, B., Leclerc-Istria, O., Noel, A., ... Nicomette, V. (2019). Computer-security-oriented escape room. IEEE Security and Privacy, 17(4), 78-83. https://doi.org/10.1109/MSEC.2019.2912700

Davis, F. D. (1989). Perceived usefulness, perceived ease of use, and user acceptance of information technology. MIS quarterly, 13(3), 319-340. https://doi.org/10.2307/249008

Dhawan, S. (2020). Online learning: A panacea in the time of COVID-19 crisis. Journal of Educational Technology Systems, 49(1), 5-22. https://doi.org/10.1177/0047239520934018

Heggart, K., \& Yoo, J. (2018). Getting the most from Google Classroom: A pedagogical framework for tertiary educators. Australian Journal of Teacher Education, 43(3), 140-153. https://doi.org/10.14221/ajte.2018v43n3.9

Hulse, R. (2019). The use and implementation of Google Classroom in a Japanese university. The Center of the Study of English Language Teaching Journal, 7, 71-105.

Indahyanti, U., \& Sukarjadi, S. (2015). Applying the technology acceptance model to measure the learning management system acceptance by students of Politeknik Sakti Surabaya. Journal Technology, 72(4). https://doi.org/10.11113/jt.v72.3927

Kassim, W. Z. W. (2021, March). Google Classroom: Malaysian University Students' Attitudes towards Its Use as Learning Management System. In First International Conference on Science, Technology, Engineering and Industrial Revolution (ICSTEIR 2020), 536, 438-446. https://doi.org/10.2991/assehr.k.210312.072

Khalil, Z. M. (2018). EFL students' perceptions towards using Google Docs and Google Classroom as online collaborative tools in learning grammar. Applied Linguistics Research Journal, 2(2), 33-48. https://doi.org/10.14744/alrj.2018.47955

Kitchakarn, O. (2015). EFL learners' attitudes towards using computers as a learning tool in language learning. Turkish Online Journal of Educational Technology-TOJET, 14(2), 52-58.

Kumar, J. A., \& Bervell, B. (2019). Google Classroom for mobile learning in higher education: Modelling the initial perceptions of students. Education and Information Technologies, 24(2), 1793-1817. https://doi.org/10.1007/s10639-018-09858-z

Lonn, S., \& Teasley, S. D. (2009). Saving time or innovating practice: Investigating perceptions and uses of Learning Management Systems. Computers and Education, 53(3), 686-694. https://doi.org/10.1016/j.compedu.2009.04.008

Malhotra, Y., \& Galletta, D. F. (1999). Extending the technology acceptance model to account for social influence: Theoretical bases and empirical validation. In Proceedings of the 32nd Annual Hawaii International Conference on Systems Sciences, 14(1). https://doi.org/10.1109/HICSS.1999.772658 
Munasinghe, P. G., \& Percy, W. W. (2016, November). Attitudes of students when using learning management systems. The Academy for Global Business Advancement (AGBA), 13th Annual World Congress, The First Sebelas Maret Conference on Entrepreneurship, Innovation and Community Development (SMARTCEIC), Ins.

Pagani, M. (2004). Determinants of adoption of third generation mobile multimedia services. Journal of Interactive Marketing, 18(3), 46-59. https://doi.org/10.1002/dir.20011

Phan, K., \& Daim, T. U. (2011). Exploring technology acceptance for mobile services. Journal of Industrial Engineering and Management (JIEM), 4(2), 339-360. https://doi.org/10.3926/jiem.2011.v4n2.p339-360

Putra, I. N. T. D. (2020). Students' attitudes in learning English for Tourism using google classroom in Mataram Tourism College. Jo-ELT (Journal of English Language Teaching) Fakultas Pendidikan Bahasa \& Seni Prodi Pendidikan Bahasa Inggris IKIP, 7(1), 9-17. https://doi.org/10.33394/jo-elt.v7i1.2735

Raja, R., \& Nagasubramani, P. C. (2018). Impact of modern technology in education. Journal of Applied and Advanced Research, 3(1), 33-35. https://doi.org/10.21839/jaar.2018.v3iS1.165

Sepyanda, M. (2018). Students' attitude toward the use of Google Classroom on translation subject in English department of Fkip Ummy Solok. English Language Teaching and Research, 2(1), 180-188.

Singh, V., \& Thurman, A. (2019). How many ways can we define online learning? A systematic literature review of definitions of online learning (1988-2018). American Journal of Distance Education, 33(4), 289-306. https://doi.org/10.1080/08923647.2019.1663082

Teo, T. S., \& Pok, S. H. (2003). Adoption of WAP-enabled mobile phones among Internet users. Omega, 31(6), 483-498. https://doi.org/10.1016/j.omega.2003.08.005

Thongphan, K. (2020). Using Google Classroom to integrate ICT to support teaching and learning in the $21^{\text {st }}$ century. Journal of Education Naresuan University, 22(1), 13-28.

Trayek, F. A., \& Hassan, S. S. S. (2013). Attitude towards the use of learning management system among university students: A case study. Turkish Online Journal of Distance Education, 14(3), 91-103.

Venkatesh, V., \& Davis, F. D. (2000). A theoretical extension of the technology acceptance model: Four $\begin{array}{lllll}\text { longitudinal field } & \text { studies. }\end{array}$ https://doi.org/10.1287/mnsc.46.2.186.11926

Venkatesh, V., Morris, M. G., Davis, G. B., \& Davis, F. D. (2003). User Acceptance of Information Technology: Toward a Unified View. MIS Quarterly, 27(3), 425-478. https://doi.org/10.2307/30036540

Weng, F., Yang, R. J., Ho, H. J., \& Su, H. M. (2018). A TAM-based study of the attitude towards use intention of multimedia among school teachers. Applied System Innovation, 1(3), 36. https://doi.org/10.3390/asi1030036

Wu, W. C. V., Hsieh, J. S. C., \& Yang, J. C. (2017). Creating an online learning community in a flipped classroom to enhance EFL learners' oral proficiency. Journal of Educational Technology and Society, 20(2), 142-157.

\section{Copyrights}

Copyright for this article is retained by the author(s), with first publication rights granted to the journal.

This is an open-access article distributed under the terms and conditions of the Creative Commons Attribution license (http://creativecommons.org/licenses/by/4.0/). 